\title{
Scientific data, ecological conversion and transformative affect
}

\begin{tabular}{|c|c|}
\hline $\begin{array}{l}\text { Author: } \\
\text { Nancy Howell }\end{array}$ & \\
\hline $\begin{array}{l}\text { Affiliations: } \\
{ }^{1} \text { Department } \\
\text { Religion, Facul } \\
\text { and Religion, } \\
\text { School of The } \\
\text { City, MO, Unit }\end{array}$ & $\begin{array}{l}\text { f Philosophy of } \\
\text { ty of Theology } \\
\text { jaint Paul } \\
\text { logy, Kansas } \\
\text { ed States }\end{array}$ \\
\hline $\begin{array}{l}{ }^{2} \text { Department } \\
\text { and Historical } \\
\text { Faculty of The } \\
\text { Religion, Univ } \\
\text { Pretoria, Preto } \\
\text { South Africa }\end{array}$ & $\begin{array}{l}\text { Systematic } \\
\text { Theology, } \\
\text { ology and } \\
\text { ersity of } \\
\text { ria, }\end{array}$ \\
\hline $\begin{array}{l}\text { Research Proje } \\
\text { Project Leader } \\
\text { Project Numb }\end{array}$ & $\begin{array}{l}\text { ect Registration: } \\
\text { : J. Buitendag } \\
\text { er: } 2402343\end{array}$ \\
\hline $\begin{array}{l}\text { Description: } \\
\text { This research } \\
\text { research proje } \\
\text { 'Understandin } \\
\text { (Theology and } \\
\text { directed by Pr } \\
\text { Buitendag, De } \\
\text { Systematic an } \\
\text { Theology, Fac } \\
\text { Theology and } \\
\text { University of }\end{array}$ & $\begin{array}{l}\text { is part of the } \\
\text { ect } \\
\text { g Reality } \\
\text { Nature)', } \\
\text { of. Dr Johan } \\
\text { partment of } \\
\text { d Historical } \\
\text { ulty of } \\
\text { Religion, } \\
\text { retoria. }\end{array}$ \\
\hline $\begin{array}{l}\text { Correspondin } \\
\text { Nancy Howell, } \\
\text { howellnr@sps }\end{array}$ & $\begin{array}{l}\text { g author: } \\
\text { t.edu }\end{array}$ \\
\hline $\begin{array}{l}\text { Dates: } \\
\text { Received: } 01 \mathrm{~F} \\
\text { Accepted: } 11 \\
\text { Published: } 27\end{array}$ & $\begin{array}{l}\text { eb. } 2021 \\
\text { Apr. } 2021 \\
\text { May } 2021\end{array}$ \\
\hline $\begin{array}{l}\text { How to cite th } \\
\text { Howell, H., } 20 \\
\text { data, ecologic } \\
\text { and transform } \\
\text { HTS Teologies } \\
\text { Theological St } \\
77(3), \text { a } 6518 \text {. } \\
\text { org/10.4102/ }\end{array}$ & $\begin{array}{l}\text { is article: } \\
21, \text { 'Scientific } \\
\text { al conversion } \\
\text { ative affect', } \\
\text { Studies/ } \\
\text { udies } \\
\text { https://doi. } \\
\text { ts.v77i3.6518 }\end{array}$ \\
\hline Read online: & \\
\hline 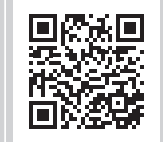 & $\begin{array}{l}\text { Scan this QR } \\
\text { code with your } \\
\text { smart phone or } \\
\text { mobile device } \\
\text { to read online. }\end{array}$ \\
\hline
\end{tabular}

Scientific data supporting rational arguments for human-made causes of climate and environmental changes might be persuasive in some contexts. Law, policy, activism and The Earth Charter similarly appear insufficient to change attitudes and behaviours. Even biblical and theological arguments fail to move some Christians beyond apathy and climate denial. Decades of ecological theology and calls for ecological conversion suggest that appeals to reason and facts are limited without an affective epistemology that join knowledge and experience to produce worldview transformation through emotions, such as awe.

Contribution: Departing from appeal to scientific data and arguments alone, the primary claim is that ecological conversion is not singularly a rational act. For broader engagement and action to mitigate climate and environmental degradation, experiential and affective encounter with nature promise wider participation and transformation.

Keywords: awe; affective epistemology; climate change; The Earth Charter; ecological conversion; ecological theology; ecowomanism; environmental racism; liberation theology; process theology.

\section{Scientific data}

While crafting this article reflecting on The Earth Charter and ecojustice, I am keenly aware of the deluge of scientific climate data. Recent issues of Science (a journal of the American Association for the Advancement of Science) underscore the efforts of scientists to stress the urgency of addressing climate change before a global community diverse in reactions - or even attention to the existing and predicted consequences of unchecked human demands on nature. With regard to rising temperatures, for example, a recent study refines the bounds of 'climate sensitivity' and 'how far temperatures will eventually rise for a doubling of atmospheric carbon dioxide' (Voosen 2020:354). The collaboration of 25 scientists from the World Climate Research Programme builds on decades of investigation and data since 1979 and predicts a warming range between 2.6 and 3.9 degrees, which eclipses the uncertainty of previous reports and eliminates the possibility of less significant climate effects (Voosen 2020:354).

The NASA (National Aeronautics and Space Administration, USA) Global Climate Change website places the data on global warming within a constellation of vital signs of planetary environmental trends. Global temperature anomaly refers to warming in global temperature compared with the previous year. The temperature anomaly in 2019 was $0.99{ }^{\circ} \mathrm{C} / 1.78{ }^{\circ} \mathrm{F}$ and the website notes that since 2001, global surface temperature records document 19 of the 20 warmest years. A second vital sign is carbon dioxide level, which reached $415 \mathrm{ppm}$ (parts per million) in November 2020. Carbon dioxide $\left(\mathrm{CO}_{2}\right)$ (greenhouse gas) concentrations are $47 \%$ higher than the 1850 pre-industrial levels and the rise is attributable to human activity (e.g. burning fossil fuels and increasing deforestation). The third vital sign is the artic sea ice minimum, which is changing at a rate of $13.1 \%$ per decade. Antarctica and Greenland ice sheets, the fourth vital sign, are decreasing by 149 billion metric tons per year. Finally, the fifth vital sign is the corresponding effect on sea level with an annual rise of $3.3 \mathrm{~mm}$ (NASA Global Climate Change 2020).

A report by Nsikan Akpan on the Public Broadcasting Service (PBS) News Hour in September 2019 notes that failure of countries to meet climate change pledges is a factor exacerbating the alarming data. China and the United States are the worst offenders amongst the top 10 countries ranked by $\mathrm{CO}_{2}$ emissions, while India is the only nation amongst the 10 to achieve climate change goals. One source indicates that China is responsible for 10.8 million metric tons and the United States is charged with 5.1 million metric tons of carbon dioxide emissions. Another source,

Copyright: () 2021. The Authors. Licensee: AOSIS. This work is licensed under the Creative Commons Attribution License. Note: Special Collection: Theology and Nature, sub-edited by Johan Buitendag (University of Pretoria). 
Climate Action Tracker (as reported in the PBS story), gives the United States a worse rating than China. In terms of the United States ranking, easing of environmental policies and deregulating industry account for limited progress in climate change goals and a flat rate of emissions, according to author Akpan (2019).

Such globally urgent data analyses are accompanied by reports on the disparate effects of ecological changes on specific populations. For example, Science reports that Colmer et al. (2020) affirmed reduction in air pollution (in terms of particulate matter) over certain census tracts in the United States (Ma 2020:503). While this is indeed progress, the data of Colmer et al. (2020) suggest a more concerning conclusion:

[T]he most polluted census tracts in 1981 remained the most polluted in 2016. The least polluted census tracts in 1981 remained the least polluted in 2016. The most exposed populations in 1981 remained the most exposed in 2016. Overall, absolute disparities have fallen, but relative disparities remain. (p. 575)

Vulnerable populations, in terms of environmental health effects and socioeconomic disadvantages, consistently experience poorer quality air. From an ecojustice perspective, the stark numbers associated with temperatures or particulate matter seem rather abstract, but their implications cause existing human socioeconomic disparities, alongside the attendant diminishment of nonhuman animal and plant flourishing.

Schell et al. (2020), also reflecting on urban environments, argued that race and class differences require a transdisciplinary perspective on ecology and evolution. Urban settings are not at all uniform and social inequalities must be taken into account along with other human factors altering landscape, biochemical processes and biological communities. Race and class diversity are determinative of 'agency, culture, power, and identity' (Schell et al. 2020:1446). Specifically, in settings aptly described in terms of systemic racism and white supremacy, economic injustice and racism are critical in environmental research. As Schell et al. (2020) note:

[S]ystemic racism and classism drive urban wealth stratification, emphasizing the need to address inequality-driven environmental heterogeneity in urban ecological and evolutionary studies. Residential segregation and colonial annexation (as well as gentrification and displacement) generate predictable ecological patterns in vegetation, air and water quality, microclimate, soils, and the built environment through the rapid influx of resources to specific areas. (p. 1446)

The details of environmental impact resulting from human activities, including economic and social policies and behaviours, require transdisciplinary perspectives. Adding to the complexity are social factors and layered inequalities beyond race and class. Attention to intersectionality in research is especially critical in urban environments of the United States 'where social inequalities shape ecological and evolutionary processes in U.S. cities and highlight the need for research that integrates justice perspectives with ecological and evolutionary dynamics' (Schell et al. 2020:1446).

An example of the complexity and diversity in ecological analysis is the subject of an article from the New York Times. Arguably, increasing incidence of severe storms and hurricanes in the Gulf states in the United States is a consequence of climate change and ecological and meteorological perspectives are incomplete explanations of recent hurricane activity. Schwartz and Tabuchi (2020) report that hazardous chemicals and pollution already threaten the health of poor, black communities located near fuel, chemical and plastics industrial sites. When storms such as Hurricane Laura (late August 2020) and Hurricane Harvey (2017) land with massive winds and rain, the industrial plants suffer damage and release toxic substances into the environment where minority communities already suffer effects from these industries on a daily basis. In the case of Hurricane Laura, the storm triggered fire and the release of toxic smoke (Schwartz \& Tabuchi 2020).

Environmental racism, which refers to racial discrimination in policies and practices characterised by injustice towards racial minorities, requires an intersectional and transdisciplinary analysis to examine the economic and political factors behind the location and privilege of certain polluting industries in very close proximity to poor and black communities suffering greater vulnerability in the wake of severe storms.

Current human and environmental crises in the United States are evidence that the human is constitutive of and integral to nature - neither separate from nature nor a 'part of nature', a phrase that can retain the sense that humans are exempt from full identification with nature. Humans, in fact, are nature undermining the health of nature. The coronavirus disease 2019 (COVID-19) pandemic is an example of the ways that humans constitute and are constituted by nature. The coronavirus disease 2019, severe acute respiratory syndrome virus (SARS) and Middle Eastern Respiratory Syndrome virus (MERS) are three recent infectious disease outbreaks and, like human immunodeficiency virus (HIV), avian influenza (H5N1), swine flu (H1N1) and Ebola are zoonotic diseases crossing species boundaries. Watsa and the Wildlife Disease Surveillance Focus Group (2020:145) report that 60\% of emerging infectious diseases (EIDs) have their origins in nonhuman animals (70\% of which originate in wildlife). Dobson et al. (2020:379) highlighted the scope of zoonotic infectious diseases: 'For a century, two new viruses per year have spilled from their natural hosts into humans'. Deforestation and wildlife trade and exploitation increase contact between humans and animals, leading to greater risk of pandemic. Matters of global health and economics intertwine. The immediacy of the COVID-19 pandemic demonstrates not only how economics and health are affected by zoonotic infection but also human social habits and practical behaviour are changed (perhaps in ways extending 
beyond the pandemic itself). The acute experience of the COVID-19 pandemic is matched by the long-term consequences of automobile and meat dependency, resulting in heart disease, chronic diseases and obesity. Climate change makes humans vulnerable to multiple threats to public health, ranging from infectious diseases to heat waves, malnutrition and social dislocation (Patz 2018:693).

\section{Compelling data?}

The previous snapshot of climate change should be compelling, but is it? Both scientists and activists are highly motivated by scientific data. For example, Greta Thunberg, a young Swedish environmental activist, is recognisable for her impassioned appeals for action on climate change. Actions by Green America (2020) and its allies have influenced the United States Senate to ban import of products and materials made with slave labour and businesses to use renewable resources, energy-efficient practices and non-genetically modified organism (GMO) and organic food sources. Science has made positive gains in more effective monitoring of indicators of climate change and environmental vulnerability, as well as identifying the cause-effect relationships contributing to global and local ecological changes (e.g. species extinction and ozone depletion). The combined efforts of science, technology, industry and governments have innovated regenerative agriculture, alternative-fuel transportation, carbon offsets, green energy and ozone layer mitigation. International collaboration has generated the 1987 Montreal Protocol (to address ozone depletion), the 1992 United Nation (UN) Framework Convention on Climate Change, the 2005 Kyoto Protocol (to reduce carbon emissions) and the 2015 Paris Agreement (to set goals to achieve climate or carbon neutrality). Admittedly, these positive steps are sometimes at beginning stages or have met serious setbacks.

Why have these passions and strategies not garnered support for behavioural, social, policy and economic changes at greater levels? One reason is that climate deniers are not convinced that human actions and human-made causes have any effect on climate. Such a view does not mean that deniers are not mindful of stewardship of the land or creation. Perhaps more damaging than denial is apathy, which disengages from the issue of climate change. One sign of hope, however, is the engagement of Christians with more activist stances on climate change (see, e.g. the Evangelical Climate Initiative or Young Evangelicals for Climate Action).

\section{The Earth Charter and theology}

The Earth Charter (launched in 2000) was a touchstone for some Christian theologies. Process theology is one Christian perspective with affinities to the integrative approach of The Earth Charter, which shares the relational and dynamic view that ecology, economics, class and race/ethnicity are interconnected. McDaniel (2006), a process thinker, summarised some similar commitments found in process theology and The Earth Charter preamble:
$[R]$ eaders familiar with process theology know that process thinkers share all of these assumptions. They believe that humanity is part of an evolving universe, that the earth is alive with a unique community of life, that living beings depend on one another for their survival and well-being, and that the future of life on earth is uncertain. They also believe that human beings have a responsibility not only to protect the vitality and diversity of the planet, but also its beauty, which takes the form of myriad forms of life both human and morethan-human. In process theology, beauty is understood to be the very aim of the universe and the aim of God. To wantonly destroy beauty in the name of progress is itself a form of sin. (p. 229)

McDaniel (2006:230) proceeded to identify the shared assessment that not only the world is threatened but also hope for a sustainable world in the future is possible with a different ethic - and the contributions of religious traditions (McDaniel adds). Muray (2006:225), a process theologian reflecting on the key principles of The Earth Charter, emphasised that the human and nonhuman natural world are not separated in the two views. Muray's (2006:225) focus on politics notes that both 'advocate' for a free, democratic, participatory, just, and sustainable community in a nonanthropocentric way, affirming the intrinsic value of the constituent elements of the nonhuman natural world'.

Process theology is not a movement embraced by all Christians and shows its limitations whenever humanity is described generically. When human diversity, especially in terms of race and class, is minimised in the discussion, nuances are missing in the analysis of the ecological issues. On this point, The Earth Charter's (2000) principles on social and economic justice push process theologians to emphasise poverty, gender, indigenous people, 'race, colour, sex, sexual orientation, religion, language and national, ethnic or social origin'.

Two key points set McDaniel's and Muray's comments in perspective, however. Firstly, they are cited here primarily because of their direct engagement of The Earth Charter. Secondly, their work stands within an extensive community of process thinkers who write about ecology. This work on theology and ecology, beginning decades before The Earth Charter, is indebted to theologians such as John B. Cobb Jr., David Ray Griffin and Catherine Keller (amongst dozens of others too numerous to mention or include in a bibliography appended to this article).

Christian theological impetus to engage ecological sustainability does not require adherence to process theology (although I consider myself to be a process theologian); other theological worldviews are also constructed to address the human relationship with the nonhuman and natural world. For example, the liberation theologies of $\operatorname{Boff}(1995,1997)$ and Gebara (1999) are instructive to process theology because of their focus on poverty, gender and race/ethnicity, and liberation theology's emphasis on economics, politics and power in relation to nature makes a strong case for the intertwined oppression of nature and the poor. However, in dialogue with process philosophy and theology, theologians 
such as Sallie McFague, Catherine Keller, Karen BakerFletcher and Rosemary Radford Ruether notably address the dynamics of race and gender in theology of ecology.

Theological worldviews might not always be persuasive for Christians, even with The Earth Charter as an ethics guide for individuals, communities and institutions, but biblical reflection on human relationship with God and the nonhuman natural world might have potential to energise Christians around action to address ecological issues and climate change. Of course, biblical texts are never free of value-laden and theological interpretations that often go unrecognised or unnuanced outside clergy and academic professions. On this point hangs the problem of hermeneutics, which can either reinforce human uniqueness, exceptionalism and separation from nature or expand the purpose of divine creation and value to encompass the whole of creation.

\section{Animals and scripture}

Clough's work On Animals (2012, 2019) explores the ambivalence of Christian biblical and theological traditions with respect to human relationships with nonhuman animals. While his theology and ethics volumes focus on animals, his writing has larger implications with relevance for ecology and human behaviours and worldviews. Clough's (2012) intention, articulated in volume 1 , is to argue that:

Christian tradition - among many other schools of thought and often in dependence on them-has come to rely on ill-considered renditions of the distinction between human beings and other animals that are implausible, unbiblical, theologically problematic and ethically misleading. (p. xii)

With the roots of human elitism in Genesis, Clough (2012:15) demonstrates in very careful and detailed work (which cannot be fully examined here) how reading of Genesis and other texts was shaped historically by philosophical trends, social pressures and technological advances, which not only generated mistaken (even heretical) interpretations of scripture but also justified the centrality of humanity in creation and human entitlement to treat nonhuman nature as means rather than end. Emphasising a contrasting reading of Genesis in light of other biblical texts, Clough highlights biblical insights including the broader and deeper scope of God's purpose in creation (see Ps 104 and Job), the mutual interdependency of creatures for survival (see Karl Barth's commentary on Gn 1 and 11), the vocation of animals in response to God's call, the vast diversity of creatures as representation of the Creator and Adam's naming of animals as acknowledgment of their particularity rather than as establishment of his power (Clough 2012:18, 28, 41, 49, 50).

To pursue the point about the influence of scripture on human thought and actions, Clough (2012:13) illustrates how diverse interpretations lead to very different ways of engaging the nonhuman natural world and understanding what it means to be human. For example, Patristic Christianity emphasised humanity as central to God's purpose in creation, while different theological arguments from Thomas Aquinas, Bonaventure and Karl Barth point to the theocentric purpose of creation (Clough 2012:19). Furthermore, Genesis 1:26-28 are the verses often cited to establish the uniqueness of humans in relation to other created beings. This pericope has sparked a variety of interpretations of the meaning of the imago Dei in humans. Clough notes Gordon Wenham's categorisation of meanings: (1) distinguishing image and likeness, (2) denoting specific mental or spiritual attributes, (3) referring to physical resemblance (Gn 5:3), (4) representing God and (5) exhibiting the capacity to relate to God (Clough 2012:65). Casting the interpretation of the imago Dei in light of the New Testament, Clough (2012:67) proposes a Christocentric interpretation identifying the imago with Christ rather than humans. The incarnation is not a humanocentric event, but a transformative event for all creatures (Clough 2012:103). Clough's (2012:101) intention is not to erase distinctions amongst species but to acknowledge the profound differences amongst creatures without reifying the imago Dei or the incarnation as doctrines that separate humanity from other creatures- and to name the incarnation as the significant event of God entering creatureliness, which reaffirms the commonality of animal creatures in relation to the incarnation (Clough 2012:103).

What Clough (2019) accomplishes is a shift in biblically informed theology that resists exploitation of animals and the destruction of habitats. The resulting theological ethic:

[M]eans recognizing other animals as fellow creatures that glorify God in their flourishing, as fellow beneficiaries of God's work of reconciling all things in Jesus Christ, and as fellow participants in the new creation. (p. xiii)

Setting the Genesis creation accounts in context with the New Testament, alongside convincing Hebrew Bible scholarship, moves Christian thought and action away from dominion, domination and destruction, as well as the dualism segregating humans from nature. While Clough (2019:57-58) focuses on the exploitation of animals and the effects of food production on environment, the wider implications of theological and ethical construction include climate change.

So, Christians find themselves with strong theological and biblical guidance and motivation for praxis, yet these nonhuman animal and nature-affirming sources are countered by strong traditions supporting human supremacy over nature. Even with the compelling scientific evidence, passionate activism and ethical guides (such as The Earth Charter), the momentum needed to make drastic changes in policy, economics and behaviour is insufficient in light of the urgency of environmental destruction and climate change.

The United States is not new to the ambivalence of biblical texts used, on the one hand, to aver the sacred worth of all persons, yet on the other hand, to commit the 'greatest blasphemy ... making God his partner in the exploitation of the Negro' (King 1968:79). In these words, Martin Luther King Jr. named the role of the pulpit in building a 'doctrine of white supremacy' that 'became a structural part of the culture' (King 1968:79). The Civil Rights Movement was the keen observer of the pattern establishing not merely human 
supremacy, but white supremacy in the United States. The opposition of African American Christianity and dominant white Christianity mirrors the ambivalence of biblical and theological constructions clashing over the sacred worth of nonhuman nature. As both expressions of supremacy are embedded in United States culture, all segments of life are affected consciously and unconsciously, so that not even law can protect nonhuman nature, non-white people or the poor. Laws created as protections are underfunded, unenforced or reversed (King 1968:86-87). The ambivalence of religion, culture and law coalesces to render the vulnerable powerless and endangered - not unexpectedly - because dominant assumptions historically link brown and black people with nature and associate whiteness with God's chosen people.

For a time, I had hoped that a different worldview could be transformative. Process philosophy and theology promise a coherent view of the relationships common to humans and nonhuman nature, making relationships more important than individualism and necessary rather than chosen. Relationality extends to the co-constitution of all beings (or becomings) in their dynamic incorporation (literally embodiment) of events and relationships in emerging moments together. Mutual co-creation, including the influence of incorporation in God, suggests a broad coinherence of God and the world compatible with an ecological worldview. The promise of such a worldview is still viable, yet I have come to believe that the mere teaching of any worldview always meets challenges from the experience, affective tone and values of those who encounter it. More than information, data and facts are necessary to engage persons in the transformation needed to meet the urgency of climate change. I propose that communicating effectively requires engaging the experience, motivations and values of conversation partners in order to evoke a kind of conversion.

\section{Ecological conversion and the neighbour}

Conversation to the neighbour, including non-human and non-living neighbours, is a theme expressed in a variety of theological reflections. Edwards (2014:2), in response to denial of both scientific facts and the climate crisis, wrote, 'We Christians need to be involved alongside others in the movement of ecological conversion'. Edwards envisions a more adequate theology of nature in relationship with God as a path towards conversion. Pope Francis (2016:250) writes in Laudato $S i$ ' that 'the ecological crisis is also a summons to profound interior conversion'. Such a conversion is ecological, in part, because 'healthy relationship with creation is one dimension of overall personal conversion', but conversion must be social and communal because 'the sum of individual good deeds' alone is inadequate in the face of the complexity of social and ecological challenges (Francis 2016:250). Conversion may be one dimension of the new start or new beginning that requires 'universal awareness' and responds to The Earth Charter's call to 'leave behind a period of self-destruction' (Francis 2016:251). Gebara (1999) adds a dimension to conversion with reference to world religions:

[I]f all of humanity, the inhabitants of the entire earth, were to take on the task of saving their own lives along with the life of the earth, world religions would inevitably make this project their own. And as they became converted to this urgent and fundamental cause, they would have to modify some of their intellectual constructs along with power structures that uphold them. (p. 7)

Conversion in these three perspectives is not spiritualised (although spiritual aspects of conversion are not necessarily irrelevant). Conversion is a transformation altering worldviews and identities through changed awareness of self, community (including religion, society, politics, economics and industry) and global ecology.

Gutiérrez (1973:194) reshapes understanding of conversion in A Theology of Liberation, where he refers to 'conversion to the neighbour'. His theological construction advances Latin American liberation theology with the argument and plea that the biblical message supports a connection between God and neighbour, particularly the poor neighbour. His rationale, citing texts from the Hebrew Bible, attends to two aspects of the connection. One is the understanding that the neighbour is God's creation. The second aspect is that loving God entails justice enacted for the sake of the poor and oppressed (Gutiérrez 1973:194-195). Moreover, the Gospel message (particularly the parable in Mt 25:31-46) grounds Gutiérrez's (1973) claim that Christ is in the neighbour:

$[W]$ e find the Lord in our encounters with men [sic], especially the poor, marginated, and exploited ones. An act of love towards them is an act of love towards God. (p. 201)

Conversion is not mere ascent to God, Christ or doctrine - conversion is action, which can be understood as sacrament (Gutiérrez 1973:201).

The intersectionality of race, class and gender in the poor, marginated and exploited is not metaphorically, but more literally related to nonhuman nature. McFague (1993:200-201) makes this point when she refers to nature as the 'new poor': 'Nature is, in our time, the new poor-oppressed, victimized, deteriorating, excluded-and deserves our solidarity in its vulnerability'. She calls for a new paradigm envisioning the world as God's body that also honours the embodiment of all creatures. The implications of the new paradigm are solidarity with the human and nonhuman oppressed ones, association of salvation with addressing 'the basic, physical needs of the earth's creatures' and a human vocation to side with the oppressed and take responsibility for stewardship of the creation (McFague 1993:200-201). Siding with the oppressed in McFague's new theological paradigm of divine and creaturely embodiment is an extension of Latin American liberation theology's exhortation to a preferential option for the poor (a phrase that originated in the Latin American Bishops' Conference at Puebla, Mexico in 1979). The plights of marginalised people and nature are truly intensely intertwined. As Pope Francis 
(2016:222) notes, the preferential option for the poor is integral to both establishment of the common good, which honours the rights and needs of the poorest humans, and implementation of a social ethic necessary for ecological justice.

In spite of scepticism about the efficacy of facts, information and ideas expressed earlier in this essay, education is nevertheless integral to the process of conversion. The question is what mode of education? Pope Francis (2016:249) associates education with the awareness of environment (perhaps a kind of conscientisation) and with a concomitant emergence of a new paradigm. The end of education is not competency with content, but an education in service of a conversion of attitudes, including an 'attitude of the heart' (Francis 2016:254).

Harris (2017:135) constructs an ecowomanist ${ }^{1}$ theo-ethical approach to understanding facts, countermemories and intersectionality. When teaching ethics, she finds that 'it is not enough .... to teach students simply about scientific facts and climate change or global warming'. Her ecowomanist method requires incorporation of the histories of black and brown people and a commitment to social justice (Harris 2017:32). She reminds us that the colonisation of people is part of the commodification of nature (Harris 2017:144) and she follows Emilie Townes in emphasising countermemory as an antidote to false or partial histories (Harris 2017:31). Countermemory moves beyond facts and objectivity to the emotive and sensory experiences that are generative of a more nuanced history beyond the colonisers' narrative. In this sense, 'ecomemory is a form of countermemory that reconstitutes traditional environmental history' (Harris 2017:31).

\section{Affective epistemology and transformation}

Gebara (1999) undertakes a critical examination of epistemology from a Latin American ecofeminist perspective. She asserts (1999:27) the contextuality of knowing and contends that knowing 'is influenced by sex, place, time, and date, and is also marked by ideological assumptions and sexist leanings'. Consequently, an ecofeminist epistemology understands knowledge as more than rational; knowing is experiential and sometimes difficult to express (Gebara 1999:48). Because so-called experiential knowing is often associated with women, the poor and marginalised perspectives, these epistemological alternatives to dominant knowledge have been dismissed as inferior to western traditions biased towards anthropocentric and androcentric epistemology and knowledge (Gebara 1999:25). Epistemological hegemony, then, implies that new paradigms are more likely to thrive amongst minorities more willing to

1.The term ecowomanist expresses the particular context of African American women in relation to ecological concerns. The term builds on a definition of womanist creat created by Walker (1983). Walker's definition articulates two relevant concepts. One is the distinction beween felated yet distinct approaches towomen's experience. The distinction is rooted in a womanist focus on the intersectionality of race, class and gender. The second is the positive association with and appreciation of womanists with nature. The term ecowomanist signifies both similarities and differences with ecofeminist approaches. entertain 'alternative styles of thinking and acting' (Gebara 1999:17). Such alternatives challenge the status quo and hierarchical power structures and move beyond 'transmitting knowledge' to 'thinking in service of ecojustice' (Gebara 1999:21). As Gebara (1999:63) explains epistemology from an ecofeminist perspective, she writes about affective epistemology: 'Emotion and passionate involvement lead us to discover things that would normally pass unobserved in the act of knowing'. Affective epistemology acknowledges a holistic dynamic between subjectivity and objectivity in contrast to a dualism of emotion and reason that turns 'reason into a rigid, cold inner figure bound by strict rules of behaviour [leading] to the imprisonment of creativity' (Gebara 1999:63). My reading of Gebara's (1999:64) epistemology interprets her point as an invitation to affectivity in epistemology, which enhances knowledge because it encompasses emotions and feelings embodied in men and women of diverse identities, social locations and cultures.

Conversation to the neighbour in human and nonhuman nature is evoked not by academic and rational arguments alone, but by affective and experiential knowing. Alfred North Whitehead's process philosophy expresses a view of creativity rooted in the experiences of relationships and events. All entities are who and what they are by virtue of a kind of self-creativity and self-determination affected by the ways they perceive and incorporate a world of data. In the context of what Whitehead calls 'internal relations', experience that shapes who we become entails an emotional response - a feeling or prehension with an affective tone influencing how events and relationships constitute our emerging selves (Howell 2000:52; Whitehead 1967:176). Because Whitehead applied internal relations, self-creativity and subjectivity to humans and other-than-human beings, his philosophy does not dichotomise humans from the rest of nature and forms an alternative view of the human relationship with nature as mutually co-creative (within the creative influence of God). My point is to note that knowledge alone does not form individual humans or communities, but experience and feeling must overtly accompany knowledge. Consequently, experience and emotion cannot be dismissed as significant factors in conversion to the neighbour and must be considered in environmental education.

Climate change data, environmental policy, education and theology or religion must engage and motivate by appeal to experience and affect. Affect predicts how a person will respond to climate data. The facts elicit denial or indifference for some resulting in resistance or apathy. For others, the facts stimulate passion, outrage and action. Instead of rational knowledge, the experiential epistemology described by Gebara suggests what may be a more effective pathway to ecological conversion. Environmental education is necessary and should not be rationally sterile nor emotionally manipulative, but could be more experiential in creating encounter with the nonhuman world in direct and compelling events and activities. A genuine and non-superficial encounter 
with nature for urban dwellers or an engagement beyond commodification or utilitarian exploitation with nature for those living closer to 'nature' has more promise for conversation to the neighbour and transformation of worldviews.

From the perspectives of psychology and neuroscience, Ihm et al. (2020:144) write about awe as a meaning-making emotion. They report that both positive and negative experiences of awe affect long-term and 'lasting changes in worldview and identity'. One of their conclusions is significant for transformation, ecological conversion and paradigm shifts:

[F]inally, experiences of awe that led to accommodative meaning-making were associated with self-reported positive changes in mood, attitudes and behaviour. These findings lend support to the hypothesis that awe-eliciting stimuli often inspire changes in meaning systems. (p. 144)

The scope of this essay does not permit reflection on the theological and historical usage of the word awe, but elaboration on the epistemological consequences of the experience of awe is relevant here. Awe is a pathway to knowing, which goes beyond mere learning (although knowing and learning are related ways of experiencing). If learning is the educational and social transmission of rationally appropriated facts, knowing is wholistic, embodied engagement of relationships and events that sometimes achieve such importance that non-rationally and or rationally the knower is constituted or even transformed by the experience of knowing. Awe is an encounter that dumbfounds learning but so disorients the experiencing subject that a reorientation of the self is evoked.

My experience of awe serves as an example. My first face-toface encounter with a 2-year-old bonobo challenged my presuppositions about the intelligence and abilities of apes. His responses to my questions, movements and actions demonstrated his ability to understand English, although I, a stranger, brought an unfamiliar voice to his circle of relationships. He was born and raised in a bicultural (human/ ape) environment with a shared symbolic language and his capacity to function within both contexts amazed me.

My generous appreciation of apes and other animals was confronted and I realised that I brought with me a rather patronising and exoticising view of animal cognitive abilities. My assumptions about nature and culture were shaken and I was awake all night processing my experience of awe. A lifetime of learning oriented me to facts about animal cognition, but the experience of awe required me to reorient myself and reconstruct my worldview regarding nonhuman animals in relation to humans and our shared relationship to God. This transformative, disorienting, contextual experience of awe exemplifies experiential epistemology as knowing beyond rationality and textbook facts.

Facts and rationality may be transformative for the few, but awe appears to be a disorienting experience that challenges worldview and beliefs in a way that '[inspires] people to explore their environments and think in new ways'
(Ihm et al. 2020:138). Without abandoning environmental education altogether, an alternative, experiential environmental education or encounter should facilitate engagement with nature as an enhanced opportunity for awe, the affective seed for ecological conversions and transformative paradigms.

The problem addressed by this essay concerns the limited effectiveness of facts and rational arguments to persuade the world's people, especially affluent people, governments and countries, to act more urgently and cooperatively to mitigate climate change and other destructive environmental consequences of human behaviour. The purpose of the discussion is identification of existing constructive resources and possibilities with promise to motivate human action towards transformative worldviews and behaviours. The human puzzle is that scientific data, biblical and theological themes and passionate activism have not created the passion and urgency needed to assure global well-being in the face of environmental challenges. Part of the tragedy is that nonhuman and human injustices alike result from continuous inaction. The Earth Charter captures the scope and complexity of the problem yet seems forgotten in light of international shortcomings in achieving climate change pledges. The modest suggestion here is that mere learning of facts and data is insufficient to persuade a world to act in concert to create ecojustice, but affective epistemology moves individuals and communities to embody knowing. Conversion to the neighbour, both nonhuman and human (ecological conversion), requires knowing that is experiential. Experience moves beyond learning to knowing in body, mind and spirit. Affective epistemology fits intersectional and particular spaces, events and relationships and motivates metanoia. While awe occurs spontaneously and cannot be fabricated, awe is made possible through embodied encounter with and attention to nonhuman nature. The scientific study of awe suggests that such experience is confrontive and transformative. Perhaps the disorientation created by experiences of awe holds promise for constructing and enacting new worldviews and behaviours.

\section{Acknowledgements}

The author acknowledges Prof. Johan Buitendag, the convenor of the research group 'Theology and Nature,' for inviting me and sponsoring the subvention fees.

\section{Competing interests}

The author declares that she has no financial or personal relationships that may have inappropriately influenced her in writing this article.

\section{Author's contributions}

N.H. is the sole author of this research article.

\section{Ethical considerations}

This article followed all ethical standards for research without direct contact with human or animal subjects. 


\section{Funding information}

This research received no specific grant from any funding agency in the public, commercial or not-for-profit sectors.

\section{Data availability}

Data sharing is not applicable to this article as no new data were created or analysed in this study.

\section{Disclaimer}

The views and opinions expressed in this article are those of the author and do not necessarily reflect the official policy or position of any affiliated agency of the author.

\section{References}

Akpan, N., 2019, Only two countries are meeting their climate pledges: Here's how the 10 worst could improve, viewed 03 April 2021, from https://www.nwpb. org/2019/09/29/only-2-countries-are-meeting-their-climate-pledges-heres-howthe-10-worst-could-improve/.

Boff, L., 1995, Ecology and liberation: A new paradigm, Orbis Books, Maryknoll, NY. Boff, L., 1997, Cry of the earth, cry of the poor, Orbis Books, Maryknoll, NY. Clough, D., 2012, On animals: Systematic theology, vol. 1, Bloomsbury, London. Clough, D., 2019, On animals: Theological ethics, vol. 2, T \& T Clark, London.

Colmer, J., Hardman, I., Shimshack, J. \& Voorheis, J., 2020, 'Disparities in $\mathrm{PM}_{2.5}$ air pollution in the United States', Science 369(6503), 575-578. https://doi. org/10.1126/science.aaz9353

Dobson, A.P., Pimm, S.L., Hannah, L., Kaufman, L., Ahumada, J.A., Ando, A.W. et al., 2020, 'Ecology and economics for pandemic prevention,' Science 369(6502), 379-381. https://doi.org/10.1126/science.abc3189

Edwards, D., 2014, Partaking of God: Trinity, evolution, and ecology, Liturgical Press, Collegeville, MN.

Gebara, I., 1999, Longing for running water: Ecofeminism and liberation, Fortress Press, Minneapolis, MN.

Green America, 2020, Victories, viewed 06 January 2021, from https://www. greenamerica.org/your-green-life/green-americas-2020-victories-0.
Gutiérrez, G., 1973, A theology of liberation: History, politics and salvation, Orbis Books, Maryknoll, NY.

Harris, M.H., 2017, Ecowomanism: African American women and earth-honoring faiths, Orbis Books, Maryknoll, NY.

Howell, N.R., 2000, A feminist cosmology: Ecology, solidarity, and metaphysics, Humanity Books, Amherst, NY.

Ihm, E.D., Paloutzian, R.F., Van Elk, M. \& Schooler, J.W., 2020, 'Awe as a meaning making emotion: On the evolution of awe and the origin of religions', in J.R. Feierman \& L. Oviedo (eds.), The evolution of religion, religiosity and theology: A multilevel and multidisciplinary approach, pp. 138-153, Routledge, London.

King, Jr. M.L., 1968, Where do we go from here: Chaos or community?, Beacon Press, Boston, MA.

Ma, L., 2020, 'Mapping the clean air haves and have-nots', Science 369(6503), 503-504. https://doi.org/10.1126/science.abb0943

McDaniel, J., 2006, 'A process approach to ecology', in J. McDaniel \& D. Bowman (eds.), Handbook of process theology, pp. 227-248, Chalice Press, St. Louis, MO.

McFague, S., 1993, The body of God: An ecological theology, Fortress Press, Minneapolis, MN.

Muray, L., 2006, 'Politics in process perspective', in J. McDaniel \& D. Bowman (eds.), Handbook of process theology, pp. 217-226, Chalice Press, St. Louis, MO.

NASA Global Climate Change, 2020, Vital signs, viewed 05 January 2021, from https:// climate.nasa.gov/vital-signs/.

Patz, J.A., 2018, 'Altered disease risk from climate change', EcoHealth 15, 693-694. https://doi.org/10.1007/s10393-018-1382-x

Francis, P., 2016, Laudato si', with commentary by S. McDonagh, Orbis Books, Maryknoll, NY.

Schell, C.J., Dyson, K., Fuentes, T.L., Des Roches, S., Harris, N.C., Miller, D.S. et al., 2020, 'The ecological and evolutionary consequences of systemic racism in urban environments', Science 369(6510), 1446. https://doi.org/10.1126/science. aay 4497

Schwartz, J. \& Tabuchi, H., 2020, 'When hurricanes lead to industrial fires, minority neighborhoods can take a hit', New York Times, 28 August, viewed 05 January 2020, from https://nyti.ms/31zb6TB.

The Earth Charter, 2000, viewed 08 January 2021, from https://earthcharter.org/wpcontent/uploads/2020/03/echarter_english.pdf?x79755.

Voosen, P., 2020, 'Earth's climate destiny finally seen more clearly', Science 369(6502), 353-355.

Walker, A., 1983, In search of our mothers' gardens, Harcourt, New York, NY.

Watsa, M. \& Wildlife Disease Surveillance Group, 2020, 'Rigorous wildlife disease surveillance', Science 369(6500), 145-147. https://doi.org/10.1126/science. abc0017

Whitehead, A.N., 1967, Adventures of ideas, Free Press, New York, NY. 